AperTO - Archivio Istituzionale Open Access dell'Università di Torino

\title{
BIOTRANSFORMATION OF INDUSTRIAL TANNINS BY FILAMENTOUS FUNGI
}

\section{This is the author's manuscript}

Original Citation:

Availability:

This version is available http://hdl.handle.net/2318/1684570

since 2019-02-11T13:55:16Z

Published version:

DOI:10.1007/s00253-018-9408-4

Terms of use:

Open Access

Anyone can freely access the full text of works made available as "Open Access". Works made available under a Creative Commons license can be used according to the terms and conditions of said license. Use of all other works requires consent of the right holder (author or publisher) if not exempted from copyright protection by the applicable law. 
AUTHORS: Valeria Prigione ${ }^{\mathrm{a}}$, Federica Spina ${ }^{\mathrm{a}}$, Valeria Tigini ${ }^{\mathrm{a}}$, Samuele Giovando ${ }^{\mathrm{b}}$ and Giovanna Cristina $\operatorname{Varese}^{\mathrm{a} *}$

AFFILIATION: ${ }^{a}$ Department of Life Sciences and Systems Biology, University of Turin, Viale Mattioli 25, 10125 Turin, Italy; ${ }^{\mathbf{b}}$ Centro Ricerche per la Chimica Fine Srl for Silvateam Spa, Via Torre 7, 12080 San Michele Mondovì (CN), Italy

*CORRESPONDING AUTHOR: Phone: +39-011-6705984; E-mail: cristina.varese@unito.it

\begin{abstract}
Tannins are secondary metabolites widely distributed in the plant kingdom. They act as growth inhibitors towards many microorganisms: upon microbial attack, they are released helping to fight the infection of plant tissues. Extraction of tannins from plants is an active industrial sector with several applications from the beginning of the industrial era. Actually, tannins have many industrial applications in oenology, animal feeding, mining and chemical industry and, in particular, in the tanning industry. But tannins are also considered very recalcitrant pollutants in wastewaters of different origins. The ability to grow on plant substrates rich in tannins and on industrial tannin preparations is traditionally considered peculiar of some species of fungi that have developed mechanisms to tolerate the toxicity of tannins producing a complex enzymatic pattern active in the transformation of these substrates, mainly by hydrolysis and oxidation. Filamentous fungi capable of degrading tannins could have a strong environmental impact as bioremediation agents mostly in the treatment of tanning wastewaters.
\end{abstract}

Keywords: industrial tannins, filamentous fungi, tannery wastewater, biotransformation, bioremediation, laccases 


\section{Introduction}

Tannins are a complex family of water-soluble polyphenolic compounds, synthesized as secondary metabolites by many plants (Haslam 1981). They are gathered from many types of trees and plants and can be present in barks, leaves, wood, as well in fruits and roots. Extraction of tannins is one of the first industrial activities related with nature, being an active industrial sector with several applications from the beginning of the industrial era. During the last two centuries several plants have been classified and proposed to be used as raw material, but only few are still of interest because really available and containing a sufficient quantity of tannins to provide economically sustainable processes. Usually, the production process is very simple, starting with a mere hot-water extraction, followed by some purification steps.

Today the total amount of industrially produced tannins in the word could be estimated around 170.000 tons per year, mainly extracted from: black wattle or mimosa (Acacia mearnsii) barks, quebracho colorado (Schinopsis lorentzii and Schinopsis balansae) hardwood, chestnut (Castanea vesca and Castanea sativa) hardwood, tara (Caesalpinia spinosa) pods extract, maritime pine (Pinus pinaster) barks, oak (Quercus spp.) hardwood, Chinese gallnut (Rhustyphina semialata) and Turkish gallnut or Aleppo galls (Quercus infectoria) (Food Chemical Codex 2003; FAO-JECFA 2005; European Pharmacopoeia 2005).

The wide application of tannins is mainly due to their ability to bind proteins, to the complexing capacity towards metals, and to the antioxidant capacity of the polyphenolic rings in their molecules. Traditionally, tannins are used in the tanning of leathers. This operation makes the animal hide a very resistant material to microbiological attack. Nowadays, tannins have many industrial applications: i) in oenology as processing aid in the clarification process they allow reducing the amount of $\mathrm{SO}_{2}$ to stabilize the color; ii) in animal feeding as alternative to antibiotics to limit microbial proliferation; iii) in mining industry, they are used in rare elements recovery, as germanium used in the electronic industry; iv) in chemical industry, hydrolysable tannins are used as raw materials to produce gallic acid for the production of displays for smartphone and TVs.

On the other hand, industrial tannins, particularly when used in the tanning industry, can represent a serious environmental problem on a global level: even though vegetable tanning agents are natural materials, they are poorly biodegradable and act as growth inhibitors towards many microorganisms ultimately affecting the receiving ecosystem.

Filamentous fungi are known to populate usual and unusual ecological niches with even a strong anthropization pressure (Chambergo and Valencia 2016) and particular attention should be given to the strains isolated from matrixes rich in tannins since they may have developed an adapted metabolism indispensable to exploit tannins as source of nourishment. Actually, fungal strains capable to perform the biotransformation of polyphenolic substances contained in tannins could have a certain environmental impact as bioremediation agents. Moreover, biotransformed tannins could have a number of applications in agriculture, in the feed and wine industries and in the tanning process, for example improving the yields of tanning or the leather quality.

This work presents an overview on the interactions between filamentous fungi and industrial tannins: we focused on how tannins exert their action against fungi and, on the other hand, on the mechanisms used by fungi to biotransform tannins. Particular attention was given to the use of filamentous fungi for bioremediation of 
wastewaters containing tannins, with the integration of the most recent data published on this application at industrial level.

\section{Chemical composition of tannins}

From a chemical point of view, it is difficult to define tannins due to their heterogeneity in terms of chemical composition and molecular weight (MW). Traditionally, tannins have been divided into two large groups: hydrolysable and condensed tannins (Haslam 1996; Scalbert 1991). Hydrolysable tannins are composed of a carbohydrate core whose hydroxyl groups are esterified with phenolic acids with a MW ranging from 300 to 5,000 Da (Mueller-Harvey and McAllan 1992). Depending on the substances produced following hydrolysis (by acids, basis or certain enzymes), hydrolysable tannins can be classified in gallotannins (yielding gallic acid) or ellagitannins (yielding ellagic acid). Tara and chestnut are representative of gallotannins and ellagitannins, respectively. Condensed tannins are oligomers where flavonoid units are condensed together with MW ranging from 1,000 to 20,000 Da. Quebracho extract is among the most industrially produced tannins predominantly composed by oligomers of profisetinidins.

The chemical composition of tannins could be explained considering as representative three of the main tannins: chestnut tannin, quebracho tannin and tara tannin. Chestnut tannin was shown to be a ellagic-type hydrolysable tannin by MALDI-TOF mass spectrometry (Pasch and Pizzi 2002). It contains castalagin (Fig. 1), which represents, with the isomer vescalagin, around $30 \%$ of the product. These substances and their higher oligomers are quite stable in chestnut tannin, and derive from rearrangement of polypentagalloylglucose naturally occurring in the chestnut wood (Pash and Pizzi 2002). The higher oligomers contain repeating units of polygalloylglucose chain where galloyl groups can be linked differently to each other (Pizzi et al. 2009). The chestnut tannin also contains digalloyl glucose, glucose and gallic acid (Radebe et al. 2013).

The composition of tara tannin is based on a polymeric structure where monomers are esters of gallic acid on a core of quinic acid. The predominant structure is a pentagalloyl quinic acid (Giovando et al. 2013). The tannin contained in Tara pods, after extraction and purification, is known as tannic acid. Tara tannin could be represented by the structure in Fig 2.

The molecular composition of condensed tannins has been studied by means of MALDI-TOF mass spectrometry. In particular, quebracho tannin is composed by polyflavonoids of the type of profisetinidins (Pasch et al. 2001). More details were reported by Venter and collaborators (2012), who identified quebracho tannin as a mixture of polyanthocyanidins oligomers consisting of linear structures as represented by the tetramer in Fig 3.

\section{Antimicrobial activity of tannins and fungal adaptation}

The antimicrobial properties of tannins are well known: they act as growth inhibitors towards many microorganisms including bacteria, yeasts, and molds. Tannins exert antibacterial effects on a wide number of foodborne pathogens and infectious microorganisms (Aguilera-Carbo et al. 2008; Akhtar et al. 2015). For example, pomegranate fruits are an important source of hydrolysable tannins (punicalin, punicalagin, pedunculagin) and flavonoids (catechin, epicatechin) largely employed in folk medicine for the treatment of 
various diseases such as ulcers, fever, diarrhoea, and microbial infections. Their pharmacological properties have been extensively studied: methanol extract of pomegranate peel has strong broad-spectrum antimicrobial properties against both gram-positive and gram-negative bacteria (Kharchoufi et al. 2018; Prashanth et al. 2001; Voravuthikunchai et al. 2005). The antibacterial efficacy of tannins is probably due to the alteration of biological membrane functionality by oxidative phosphorylation uncoupling, because of their lipophilic properties, causing the loss of cytoplasmic content (Cabral et al. 2013; Pane et al. 2016; Gupta et al. 2017).

Regarding the fungicide action of tannins, Elsherbiny and collaborators (2016) demonstrated that the methanol extract of pomegranate peels has a significant antifungal activity on the spore germination and mycelial growth of Fusarium sambucinum, one of the causal agents of potato tubers dry rot. Scanning and transmission electron microscopy observations revealed morphological modifications of hyphae such as curling, twisting and collapse, and dramatic changes of the cytoplasm and organelles. These changes could be the consequence of the disruption of cell permeability, which resulted in imbalance in internal osmotic pressure (Plodpai et al. 2013; Elsherbiny et al. 2016). Analogously, Kharchoufi et al. (2018), in a recent study about the fungicide action of pomegranate peel extract on Penicillium digitatum, observed by optic microscopy noticeable changes in the shape of hyphae, which appeared wilted and coiled. Other filamentous fungi susceptible to the action of the same extract were Penicillium italicum, Rhizopus stolonifer and Botrytis cinerea (Tehranifar et al. 2011).

With reference to yeasts, Endo and collaborators (2010) reported an irregular budding pattern and pseudohyphae in Candida albicans when treated with punicalagin and remarkable morphological alterations, which were visible by electron microscopy such as thickened cell wall, changes in the space between cell wall and the plasma membrane, vacuoles, and a reduction in cytoplasmic content. Two other Candida species, C. stellatoidea and C. guilliermondii were found to be susceptible to the antifungal activity of tannins (Haslan 1996; Vasconcelos et al. 2003).

Despite tannins have such well-documented antimicrobial activities, some filamentous fungi, yeasts and bacteria are resistant to them by the development of adaptive mechanisms and pathways for their degradation in natural habitats, where they can exploit ecological niches precluded to other organisms. For example Panno and collaborators (2013) studied the microbial community associated to Posidonia oceanica, a seagrass known for the high amount of tannins ranging between 55 and $95 \mu \mathrm{g} / \mathrm{g}$ of dry weight of plant material. A total of 88 taxa were isolated, mainly Ascomycota, and many strains were recognized as good producers of tannases active in presence of high salt concentrations. These fungi, hence, were able to colonize and exploit lignocellulose residues, playing important ecological roles in marine environments (thanks to the substrate detoxification operated by tanning degrading fungi, leaves and rhizomes of $P$. oceanica may become available to other organisms) but can also be very useful in different biotechnological areas.

Some phytopathogenic Ascochyta species produce tannases, which help the invasion into the host plant by hydrolyzing the complex polyphenolic materials present in the bark of plants that usually confer protection against the attacking pathogens (Lekha and Losane, 1997). On the other hand, in mycorrhizal symbiosis, the ability to degrade tannic acid by Oidiodendron sp. may be necessary for the successful colonization of root cortical cells of members of Ericaceae (Li et al. 2006). 
The ability to grow on plant substrates rich in tannins and on industrial tannin preparations is traditionally considered peculiar of some species of the genera Penicillium and Aspergillus, and in particular, of species belonging to the "black Aspergilli" group. In addition to Ascomycota, this ability seems to be widespread in the fungal kingdom, involving also Basidiomycota and Mucoromycota.

More than a century ago Knudson (1913) reported for the first time, that tannic acid could be degraded by an Aspergillus niger strain. In 1969, Lewis and Starkey reported that pure cultures of some terrestrial fungi grew on media containing tannins as sole carbon source, and some Aspergillus and Penicillium species grew on the surface of tannery pits and tannery wastes, and tannin-rich woods such as quebracho and chestnut. Moreover, different sources of tannins were compared, and both condensed and hydrolysable tannins were used as substrates. Aspergillus, Penicillium, Fomes, Polysporus and Trametes were shown to grow better on tannic acid (gallotannin) than on chestnut tannin (ellagitannin) or wattle tannin (condensed tannin) (Bhat et al. 1998).

The number of fungal species capable of growing in the presence of tannins, possibly using them as carbon source, is continuously increasing (Table 1). For example, Bhoite and Murthy (2015) cultured Penicillium verrucosum on coffee pulp as sole nutrient, and obtained up to $65 \%$ tannin degradation with up to 3.93 -fold higher tannase concentration. More recently, Prigione and collaborators (2018), in a study on the mycobiota of industrial tannins, showed the ability of 125 isolates belonging to 10 fungal species to grow on culture media containing different types of industrial tannins as sole carbon source. In particular, five species (namely Aspergillus acidus, Aspergillus costaricaensis, Aspergillus vadensis, Penicillium minioluteum, Talaromyces subinflatus) had never been isolated from similar substrates, nor their ability to use tannins as the sole carbon source was reported before. Moreover, 10 fungal strains displayed a strong activity on chestnut and tara tannins in biotransformation tests by submerged fermentation.

The study of Prigione and collaborators (2018) highlighted that the choice of isolating autochthonous microorganisms is an appropriate practice to select strains with high applicative potential. Actually, tannases production is a strain-specific feature and fungi isolated from tannins are certainly adapted to these extreme environments, since the high tannin content exerts a selective pressure on the fungal community. Therefore, the isolates likely developed a unique adapted metabolism in order to exploit tannins as source of nourishment.

\section{Biotransformation mechanisms}

Some fungi have developed mechanisms to tolerate the toxicity of tannins, indeed producing a complex enzymatic pattern active in the transformation of these substrates. Hydrolysis and oxidation are the main reactions that lead to tannins biotransformation.

\section{Tannases}

Tannases are the main enzymatic class involved in the tannins hydrolysis. Tannases, namely tannin acyl hydrolase (EC 3.1.1.20), hydrolyze ester and depside bonds of hydrolysable tannins to produce glucose and gallic acid (Lekha and Lonsane 1997). Known to be produced also by bacteria (Reveron et al. 2017; Tomás Cortázar et al. 2018) and plants (Bains et al. 2009), fungal tannases are well known for their catalytic versatility.

Numerous fungi are known to be tannases producers, including strains belonging to Penicillium, Aspergillus, Neurospora, Trichothecium, Fusarium, Trichoderma, Paecilomyces, Emericella, Lenzites genera 
(Schons et al. 2011; Ordonez et al. 2011; Bressan Gonçalves et al. 2013; Zakipour-Molkabadi et al. 2013; Herrera Bravo de Laguna et al., 2015). The choice of the fungus to be used is a critical point. For instance, Zakipour-Molkabadi and collaborators (2013) inoculated eight strains in the presence of tannic acid 1\% as sole carbon source: tannase activity was always lower than $1 \mathrm{U} / \mathrm{ml}$ with the exception of Penicillium sp. that produced $4.33 \mathrm{U} / \mathrm{ml}$ after $96 \mathrm{~h}$.

As regards their cellular localization, contrasting results have been reported. Known to be extracellular enzymes, de Böer and collaborators (2009) found specific secretion signal sequences on the yeast Arxula adeninivorans tannase gene. On the contrary, Aspergillus niger and Verticillium sp. produced both extracellular and intracellular tannases (Aguilar et al. 2001; Kasieczka-Burnecka et al. 2007); the productivity of intracellular tannases was even higher than extracellular enzymes for Aspergillus aculeatus (Banerjee et al. 2001).

Purified tannases have been obtained from A. niger (Mata-Gómez et al. 2009, Ramos et al. 2011), Aspergillus carbonarius (Serrani Valera et al. 2015), Aspergillus awamori (Beena et al. 2011), Aspergillus oryzae (Abdel-Naby et al. 2016), A. adeninivorans (Böer et al. 2009), Lenzites elegans (Ordonez et al. 2011), Penicillium sp. (Zakipour-Molkabadi et al. 2013) and the antarctic strain Verticillium sp. (Kasieczka-Burnecka et al. 2007) among others. Thanks to this information, the phenomenon at the base of tannase production has been clarified. Tannases production is an inducible process that can be obtained both in solid state and liquid fermentation. The process is mostly controlled by the source of $\mathrm{C}$ and the presence in the medium of structural constituents of tannic acid pyrogallol, methyl gallate and gallic acid (Aguilar et al. 2007; Zakipour-Molkabadi et al. 2013).

According to their ecological role, fungi respond to tannins-rich substrates by producing tannases: agricultural byproducts (i.e. tamarind seed powder, palm kernel cake, tea and coffee residues, olive mill wastewater, etc.) could be used for fungal fermentation to produce high-value products like tannases (Aissam et al. 2005; Jana et al. 2012; Baik et al. 2014; Sabu et al. 2015, Bhoite and Murthy 2015). These findings were confirmed by in-depth analysis of tannase genes. ATAN1 is the tannase gene of A. adeninivorans, a common fungus model whose tannase was characterized and cloned. Its activation is controlled by a CAAT box-like sequence but no TATA box-like sequence were identified: expression profile revealed that tannase production is induced by tannic acid or gallic acid, whereas glucose did not trigger the same effect. When glucose feeding was shifted to tannic acid or gallic acid, the gene was rapidly activated and, after $2 \mathrm{~h}$, the enzymes were already detectable (Böer et al. 2009). However, there are still few unclarified steps of the induction mechanism, including the role of tannin-related compounds as synthesis inducers. For instance, gallic acid enhanced tannase productivity of $A$. niger at higher extent in solid-state fermentation rather than ineffective submerged cultures (Aguilar et al. 2001).

Fungal tannases have a $\mathrm{pH}$ optimum at acidic values and are mildly tolerant to high $\mathrm{pH}$ and temperature. These data are strictly dependent of the microbial enzymatic source, according probably to isolation origin and adaptation skills evolved by each fungus. Tannase activity is usually maximal at $\mathrm{pH} 5.5$ and $35^{\circ} \mathrm{C}$ and are stable at pH 5-6 and $25-35^{\circ} \mathrm{C}$ (El-Tanash et al. 2011; Zakipour-Molkabadi et al. 2013). Particular attention is given to those enzymes with better catalytic features. Tannase from $P$. variotii showed $95 \%$ of activity recovery in the range of 3.5-7.5 $\mathrm{pH}$ and $20-50^{\circ} \mathrm{C}$ (Schons et al. 2011). The Basidiomycota L. elegans secreted a tannase 
effective from 40 to $60^{\circ} \mathrm{C}$, whose activity was only halved at $80^{\circ} \mathrm{C}$ (Ordonez et al. 2011). Promoting structural modifications on the active site, tannase activity is generally inhibited by heavy metals and metal ions (Serrani Valera et al. 2015; Yao et al. 2014), even though some exceptions can be found. Although being inhibited by metal ions, a tannase from $A$. carbonarius was not perturbed by $\mathrm{Ag}^{+}$: the activity even increased up to $32 \%$ according to the $\mathrm{Ag}_{2} \mathrm{SO}_{4}$ concentration (Serrani Valera et al. 2015). Interestingly tannases can be considered solvent- and salt-tolerant enzymes, making them good candidates for biotechnological application in wastewater treatment (Serrani Valera et al. 2015). Indeed tannase from Penicillium sp. maintained 50\% of the activity in the presence of $1 \mathrm{M} \mathrm{NaCl}$ after 24 hours (Zakipour-Molkabadi et al. 2013). Activity recovery of tannase from $A$. carbonarius was always higher than $80 \%$ after exposition to detergents (SDS and Tween-20) and organic solvents (methanol, ethanol, acetone, isopropanol, n-butanol and glycerol) (Serrani Valera et al. 2015).

Enzymes may be used for industrial application, becoming an intriguing alternative to whole cell systems. Although a time-saving technology requiring very low operational control, enzymes are still considered as a high-cost system with room for improvement at their catalytic stability over time and stressors (Rao et al. 2014). Due to their biochemical properties, the demand for industrial enzymes is increasing, asking for the development of solutions feasible for industrial application. Stable and re-usable enzymes may overcome technical and economic drawbacks, driving to increasing interest in immobilized enzymes (Arca-Ramos et al. 2018). Tannases have been immobilized using several supports as Eupergit ${ }^{\circledR}$ (Crestini and Lange 2015), carbon nanotubes (Ong and Annuar 2018), gelatin (El-Tanash et al. 2011), sodium alginate, gellan gum and pectin (Schons et al. 2011), agarose (Bressan Goncalves et al. 2013), magnetic diatomaceous (Silva de Lima et al. 2018). Advanced techniques have been successfully applied as cross-linking (Ong and Annuar 2018), microencapsulation in calcium alginate membranes ( $\mathrm{Yu}$ et al. 2004), etc. The choice of the immobilization method has a central role in the success of the treatment, because inadequate systems can influence the diffusion of molecules and products (El-Tanash et al. 2011). Respect to free tannases, immobilization allows repetitive cycles (Ong and Annuar et al. 2018) and enhances the enzymatic stability, enlarging the $\mathrm{pH}$ and temperature range of action ( $\mathrm{Yu}$ et al. 2004; Schons et al. 2011; Kumar et al. 2015). Immobilization can also protect the enzymes from inhibition effects played by metal ions. Tannases from A. aculeatus were more stable by metal ions disturbance when immobilized on gelatin: in the presence of several ions, the activity recovery was always higher than free enzymes, with peaks of $20 \%$ activity increase for $\mathrm{K}^{+}$(El-Tanash et al. 2011). Positive effects can be also observed in the catalytic efficiency of the immobilized enzymes. For instance, tannase from A. niger on sepharose beads better converted methyl gallate into gallic acid: process yields increased from $30 \%$ up to $40 \%$ (Sharma et al. 2002). According to the authors, immobilized enzymes are less perturbed by the competitive inhibition by gallic acid, which is instead electrostatically pushed away from the positively charge support.

The competitiveness of tannase-based methodology lays the foundation on the rapidity of the catalyzed reactions, positively affecting the feasibility and the sustainability of the proposed methodology. A. oryzae tannase can hydrolyse tannic acid forming at first penta-, tetra- and tri- galloyglucose during the first $10 \mathrm{~min}$, which are further transformed in gallic acid and mono galloylglucose after $15 \mathrm{~min}$. The reaction continues having gallic acid as the sole end product after 35 min incubation (Abdel-Naby et al. 2016). Immobilized and free tannases can be indeed applied in several biotechnological fields as environmental bioremediation, 
pharmaceutical and food industry (e.g. clarification of beverage, manufacture of instant tea, etc.). Tannase from marine A. awamori catalyzed transesterification reaction of tannic acid producing propyl gallate, an antioxidant used in the food industry with nutraceutical importance (Beena et al. 2011). Tannase from marine A. niger transformed green tea extracts, rich of polyphenols that are responsible for the formation of sediment and haze (Baik et al. 2014). P. verrucosum tannase treatment of pomegrade and aonla juice enhanced the clarity and removed astringency (Bhoite and Murthy 2015). It has been proved that tannase-treated straw have a reduced content of tannins, along with an improved nutritional content useful for cattle feed (Raghuwanshi et al. 2014).

\section{Gallic acid decarboxylases}

Among tannin-transforming enzymes, tannases are not the only enzymes involved. Following gallic acid production by tannases, gallic acid decarboxylases (gallate decarboxylase, EC 4.1.1.59) indeed catalyze its decarboxylation to pyrogallol. Known to be produced mainly by bacteria (Zeida et al. 1998; Jiménez et al. 2013), very few of these enzymes have been characterized because highly unstable and known to be sensitive to oxygen (Zeida et al. 1998). Recently also fungi have been identified as gallate decarboxylase producers. The first report of fungal nonoxidative decarboxylation of tannins is the study of Sietmann and collaborators (2010) on the yeast $A$. adeninivorans: pyrogallol was the main reaction product of gallic acid decarboxylation. Studying the transformation pathway, the authors suggested pyrogallol as the substrate for further ring fission, forming as end-product the 2-hydroxymuconic acid. This enzyme was further purified and characterized (Meier et al. 2017). The optimal $\mathrm{pH}$ and temperature is between 5.6 and 7.1, and between 25 and $45^{\circ} \mathrm{C}$, respectively. The enzyme was almost completely inhibited by buffer and some metal ions.

Gallic acid decarboxylases expression is specifically controlled by gallic acid, whereas other hydroxybenzoic acids do not induce its production (Meier et al. 2017). Noteworthy, gallic acid induce also catechol-1,2-dioxygenase, even though its role in the tannins degradation is currently unclear (Meier et al. 2017). This observation may suggest that these enzymes are specifically involved in the transformation pathway of gallic acid. Kinetic analysis confirmed this assumption: both bacterial and fungal gallic acid decarboxylases have a high affinity for gallic acid, catalyzing reactions against gallic acid but not on structural analogues as benzoic acid derivatives (Zeida et al. 1998; Meier et al. 2017).

\section{Laccases}

Fungi also catalyze oxidation reactions leading to the transformation of phenolic compounds as tannins by extracellular oxidative reductases as laccases (EC 1.10.3.2) and peroxidases (EC 1.11.1.x) that are among the most known and studied fungal enzymes (Janusz et al. 2017). Although not constitutively produced by fungi, gene transcription is usually regulated by metal ions and catabolic byproducts of lignin and tannin (Martinez 2002; Piscitelli et al. 2011). Natural lignin-based materials rich of tannins as corn cob, wheat straw, saw dust and evergreen oak litter can be used as growth medium to trigger extracellular secretion of oxidoreductases (Tagger et al. 1998; Sahay et al. 2009).

Laccases are involved in the gallotannin, ellagitannin and proanthocyanidins biosynthesis by plants (Niemetz and Gross 2005; Hu et al. 2013) whereas in fungi may trigger oxidation cascades against tannins and 
their derivates. Indeed, laccases have a high affinity for phenol monomers including catechol, pyrogallol and gallic acid (Sahay et al. 2009; Itoh et al. 2016; Zerva et al. 2016). The reaction often leads to the production of dimers and phenol polymers (Zerva et al. 2016).

Although hydrolyzable tannins are usually a better substrate for laccase than condensed tannins (Widsten et al. 2009), laccase from M. termophila was used to perform the grafting of polyphenols (condensed and hydroxypropylated tannins) to improve wood preservation reducing the water absorption and enhancing the hydrophobic properties (Filgueira et al. 2017). Laccases from Myceliophthora termophila were also applied in the fiberboard manufacturing, providing an ecological sustainable alternative to common process that use formaldehyde-based adhesives: formaldehyde emissions pose indeed important health concern (Widsten et al. 2009). Laccases activated tannin and wood fibers, by forming radicals that later create covalent bonds among fibers by radical coupling: when the interfiber bonds are widespread on the surface, the adhesive effect can be considered similar to synthetic resins (Widsten et al. 2009; González-García et al. 2011). This reaction is at the base of wood decay prevention strategies, where tannins are under study as natural preservatives against wood decaying fungi. Laccase from Trametes hirsuta catalyzed polymerization reactions to fix phenolic preservatives as tannin acid and vanillin acid to the wood fibers: the treatment enhanced the resistance to microbial attack by the brown-rot fungus Coniophora puteana and the white-rot fungus Coriolus versicolor (Ratto et al. 2004).

\section{Peroxidases}

The role of peroxidases in tannins transformation has been mostly unexplored, even though they are recognized among the most powerful fungal enzymes. Despite the redox potential of peroxidases falls in the range of $1100-1500 \mathrm{mV}$, significantly higher than laccases, stability issues mostly limited their application (Ravichandran and Sridhar 2017). Post-translational modifications are under study to enhance this feature (SáezJiménez et al. 2015). Even though gallic acid is involved in peroxidase metabolism as production inducer or oxidation cascade mediator (Mishra and Jana 2017; Mishra et al. 2017), very few reports studied their actual involvement in tannin degradation. Heme peroxidases from Phanerochaete chrysosporium were capable to degrade tannic acid and condensed tannins, and removed tannin components from spent tan liquor. Studying the enzymatic kinetic, authors suggested that complexation reactions were indeed followed by the cleavage of ethereal linkage, hydroxylation reaction, aromatic ring opening and ultimately oxidation to the end products (Gnanamani et al. 2001).

\section{Fungal bioremediation of wastewaters containing tannins}

Tannins are considered very recalcitrant pollutants in wastewaters of different origins, e.g. winery and beer wastewater (Moreira et al. 2015; Yague et al. 2000), pulp and paper mill effluents (Vepsalainen et al. 2011), olive mill wastewaters (Aissam et al. 2005), landfill leachates (Bardi et al. 2017b) and mainly tannery wastewaters ( $\mathrm{He}$ et al. 2007). The core of wastewater treatment plants (WWTPs) consists of engineered biological ecosystems (activated sludge) based on bacteria that allow an economical and sustainable treatment of wastewaters (Leyva-Diaz et al. 2017). However, bacteria are ineffective in the removal of compounds characterized by high toxicity and recalcitrance, such as tannins (Lofrano et al. 2013; He et al. 2007). A 
substantial percentage of the Total Organic Carbon (TOC) in the effluent of the biological treatment phase in tannery WWTPs is attributable to natural and synthetic tannins (Munz et al. 2009). Condensed tannins, in particular, are more resistant to microbial attack than hydrolysable ones and have stronger toxic effect on microbial populations (Mutabaruka et al. 2007). Despite a direct inhibiting effect cannot be associated with the tannin concentration in the effluent, a lower specific growth rates of ammonium and nitrite oxidising bacteria indicates a strong environmental pressure due to the tannery wastewater (Munz et al. 2009). In this regard, the WWTP implementation with a fungal treatment could be useful to achieve better depuration results (Zhang et al. 2015).

Fungal treatment aimed to the tannin removal can be based on three mechanisms: adsorption (Natarajant and Manivasang, 2018), degradation (Zhang et al. 2015), and precipitation induced by extracellular enzymatic polymerisation (Yamaguchi et al. 1998). These mechanisms could run at the same time or be sequential (Song and Burns 2005).

In general, biosorption occurs within the first few hours but a change in the process conditions or long term operations could cause backward transformation or desorption (Tigini and Varese, 2018). Besides, this option requires an adequate disposal or further treatment of the loaded biosorbent, since it consists in the transfer and concentration of pollutants from one medium to another. For these reasons, fungal biosorption appears more adequate for the treatment of chromium tannery wastewaters, aimed to the recovery of chromium ions (Hintermeyer and Tavani, 2013).

Biodegradation is the most investigated strategy in fungal bioremediation of vegetable tanning wastewaters. Despite enzymes can be applied, economic drawbacks have discouraged their investigation in this field (Aguilar et al. 2007, Govindarajan et al. 2016). A whole-cell system can degrade tannins, despite the lack of information about the acting metabolic pathways (Chávez-González et al. 2012). Several fungal species, mainly belonging to Aspergillus, Penicillium, Paecilomyces and Fusarium genera have been reported to utilize both hydrolysable and condensed tannins as sole carbon source. However, no report of their application at real scale on vegetable tannery wastewaters is reported (Chaudhary et al. 2017). An application to a real scale encounters several issues to be addressed, since typical conditions of conventional WWTPs are unfavourable to fungal growth. The scale up of an effective fungal treatment is still an actual challenge.

The first goal is to obtain a stable system in real operative conditions where allochthonous fungi are often not able to compete with autochthonous microorganisms (Svobodová and Novotný, 2018). In particular, during the start-up period the faster growth rate of bacteria can cause the fungal growth suppression and mycelium disgregation, that turn in outclass of fungi (Rene et al., 2010). Moreover, bacterial colonisation can induce a drop in enzymatic activity, deeply affecting the treatment effectiveness (Gao et al. 2008). Autochthonous fungi can also affect the efficiency of the inoculum development in bioreactors as happens in the presence of Trichoderma spp., mycoparasites able to degrade tannins, and consequently often present in tannery wastewaters (Badia-Fabregat et al. 2017; Tigini et al. 2018). Therefore, many studies were indeed carried out in sterile conditions, but sterilization is impracticable in a full-scale reactor system, due to high operational costs (Gao et al. 2008). 
Different strategies have been suggested to enhance the resistance of fungi in non-sterile conditions. Mature and well-developed fungal inoculum, possibly immobilised in an adequate support, is recommended (Spina et al. 2012; Bardi et al. 2017). The control of the environmental conditions (e.g. pH adjustment, nitrogen sources) may support the success of fungal bioreactors (Bardi et al. 2017b; Wu et al. 2018). To avoid negative effects on fungal metabolism and biomass growth, these operations must be carefully optimised (Badia-Fabregat et al. 2017; Wu et al. 2018).

The addition of co-substrates as selective carbon source, not exploitable by bacteria or with antibacterial effect, may help fungi to compete with them (Badia-Fabregat et al. 2017; Bardi et al. 2017b). Moreover, alternative carbon sources could be required by white rot fungi for their growth, as they often degrade pollutants with a co-metabolism mechanism, as well as enhancing the tannase production (Ordonez et al. 2011). This is true also for fungi that produce oxidative enzymes with the aim of detoxifying their environment causing tannin precipitation by polymerisation. For instance, malt extract strongly enhanced quebracho removal by Aspergillus tubingensis (Spennati et al. 2017). This species produces high amount of laccases in addition to tannases (Spennati et al. 2016; Iqbal et al. 2018). Alternatively, lignocellulose material would be a strategic choice, operating a selective pressure against bacteria and supporting fungal co-metabolinsm at the same time (Spennati et al. 2016). However, the co-substrate addition should be evaluated in order to be a sustainable option when applied in a WWTP. Besides, strong catabolite repression of tannase synthesis in A. niger can occur when alternative carbon source is added, probably due to changes in carbon/nitrogen ratio (Aguilar et al. 2001). This must be kept in mind in the case of treatments specifically aimed to tannin degradation by means of tannases.

Lastly, bioreactor configurations and elevated retention time (1-3 days) are also useful to acquire a better understanding of the process, which facilitates the up-scaling and highlights possible unexpected effects like the ecotoxicity increase or excessive biomass growth (Spina et al. 2012; Chanda et al. 2016; Spennati et al. 2017).

Another future challenge is the investigation of microbial relationships, with the aim to enhancing the exploitation of fungal natural degradative ability towards tannins. In nature as well in wastewater oxidative biological treatment, microorganisms do not exist in isolated form, and they coexist with each other, establishing biological competences among the interacting species. Biotransformation in nature is commonly a combination of metabolic pathways from different microorganisms (Ijoma and Tekere 2017). Moreover, microbial consortia are more vigorous to environmental variations and better survive in nutrient limitation thanks to metabolites exchanging or by trading molecular signals. Each biological entity identifies the presence of other organisms in the consortium and acts in response to that (Chaudhary et al. 2017). Microbial consortia can serve unknown functions potentially inducing alternative degradation pathways and metabolites in bioreactors. In an established consortium, several enzymatic isoforms from different species may be complementary in the degradation of complex matrices, and mutualistic or antagonistic relationships may ultimately enhance enzymatic production (Ijoma and Tekere 2017). Furthermore, different species showed specific activity dependent on the tannin to be treated (Prigione et al. 2018). Likewise some strains are more effective against the Chemical Oxygen Demand (COD) and other on the total phenol content (Perovano et al. 2011). The development of a consortium is sometimes recommended, in order to achieve better yields in the bioremediation of tannins wastewaters. 
The study of autochthonous fungal consortia could enhance their exploitation in in-situ bioaugmentation strategy, too. The presence of fungi in activated sludge is established (Evans and Seviour 2012; Fathi et al. 2017) as the activity specificity according to pollutants of interest (Tigini et al. 2018). Nevertheless, during normal operational condition, hyphal colonisation of flocks in activated sludge is not predominant, so their role has been underestimated up to now (Liu et al. 2017). Besides high tolerance and adaptation to pollutant toxicity and microorganisms' competition (Herrero and Stukey 2015), fungi could be involved both in the direct degradation of pollutants, and in the formation/stabilisation of adequate ecosystems for the development of degrading organisms (Liu et al. 2017).

Some possible configurations for tannin fungal treatment were hypothesized for future applications based on different tannin concentrations (Spennati et al. 2018). Firstly, vegetable tannin bath would be treated with an optimized process based on fungal bioreactors, before the conventional activated sludge process, exploiting high selective pressure given by high tannin concentration as an important factor for fungal biofilm stability. However, the maximum load of tannins treatable by fungi should be established for evaluating a dilution of tannery wastewater in case. Another possible strategy could be the treatment in a side-stream reactor with a recirculation system in active sludge, with the aim to remove the residual recalcitrant COD. The adjustment of nutrient load in the effluent could allow obtaining a stable fungal biofilm. Fungi predominate in the microbiome of WWTPs treating nitrogen deficient wastes, indeed (Evans and Seviour 2012). In any case, scientists are surely called to face the challenge of implementing of WWTPs with real scale fungal treatment in the next future.

\section{Conclusions}

Filamentous fungi are undoubtedly endowed with high application potential in the field of industrial tannins biotransformation. The more tannins are finding new applications the more fungi will play an increasingly important role both in biotransformed tannin production and in tannin biodegradation. Nevertheless, even though there are numerous references to the isolation of fungi from soils, plant material or extreme environments capable of degrading tannins, the report of successful applications at real scale are still missing. The actual challenge in the next future is to harness the potential of fungi in order to open the way for tannin exploitation, taking advantage of the infinite applicative resources of these heterogeneous compounds.

Compliance with ethical standards: This article does not contain any studies with human participants performed by any of the authors.

Conflict of Interest: The authors declare that they have no conflict of interest.

\section{References}

Abdel-Naby MA, El-Tanash AB, Sherief ADA (2016) Structural characterization, catalytic, kinetic and thermodynamic properties of Aspergillus oryzae tannase. Int J Biol Macromol 92:803-811. doi: 10.1016/j.ijbiomac.2016.06.098 
Aguilar CN, Augur C, Favela-Torres E, Viniegra-González G (2001) Production of tannase by Aspergillus niger Aa-20 in submerged and solid-state fermentation: influence of glucose and tannic acid. J Ind Microbiol Biotechnol 26:296-302. doi: 10.1038/sj.jim.7000132

Aguilar CN, Rodriguez R, Gutierrez-Sanchez G, Augur C, Favela-Torres E, Prado-Barragan LA, RamirezCoronel A, Contreras-Esquivel JC (2007) Microbial tannases: advances and perspectives. Appl Microbiol Biotechnol 76:47-59. doi:10.1007/s00253-007-1000-2

Aguilera-Carbo A, Augur C, Prado-Barragan LA, Favela-Torres E, Aguilar CN (2008) Microbial production of ellagic acid and biodegradation of ellagitannins. Appl Microbiol Biotechnol 78:189-199. doi: 10.1007/s00253007-1276-2

Aissam H, Errachidi F, Penninckx MJ, Merzouki M, Benlemlih M (2005) Production of tannase by Aspergillus niger HA37 growing on tannic acid and Olive Mill Waste Waters. World J Microbiol Biotechnol 21:609-614. doi: $10.1007 / \mathrm{s} 11274-004-3554-9$

Akhtar S, Ismail T, Fraternale D, Sestili P (2015) Pomegranate peel and peel extracts: chemistry and food features. Food Chem 174: 417-425. doi: 10.1016/j.foodchem.2014.11.035

Arca-Ramos A, Eibes G, Feijoo G, Lema Jm, Moreira MT (2018) Enzymatic reactors for the removal of recalcitrant compounds in wastewater. Biocatal Biotransformation 36(3):195-215. doi: $10.1080 / 10242422.2017 .1315411$

Badia-Fabregat M, Lucas D, Tuomivirta T, Fritze H, Pennanen T, Rodriguez-Mozaz S, Barcel D, Caminal G, Vicent T (2017) Study of the effect of the bacterial and fungal communities present in real wastewater effluents on the performance of fungal treatments. Sci Total Environ 579:366-377. doi: 10.1016/j.scitotenv.2016.11.088

Baik JH, Suh HJ, Cho SY, Park Y, Choi H.-S (2014) Differential activities of fungi-derived tannases on biotransformation and substrate inhibition in green tea extract. J Biosci Bioen 118(5):546-553. doi: 10.1016/j.jbiosc.2014.04.012

Bains G, Kumar AS, Rudrappa T, Alff, E, Hanson TE, Bais HP (2009) Native plant and microbial contributions to a negative plant-plant interaction. Plant Physiol 151:2145-2151. doi: 10.1104/pp.109.146407

Bajpai B, Patil S (1996) Tannin acyl hydrolase activity of Aspergillus, Penicillium, Fusarium and Trichoderma. World J Microbiol Biotechnol 12:217-220. doi: 10.1007/BF00360918

Bajpai B, Patil S (1997) Introduction of tannin acyl hydrolase (EC 3.1.1.20) activity on some members of fungi imperfecti. Enzyme Microb Technol 20:612-614

Banerjee D, Mondal K, Bikas R (2001) Production and characterization of extracellular and intracellular tannase from newly isolated Aspergillus aculeatus DBF9. J Basic Microbiol 6:313-318. doi: 10.1002/15214028(200112)41:6 
Bardi A, Yuan Q, Siracusa G, Chicca I, Islam M, Spennati F, Tigini V, Di Gregorio S, Levin DB, Petroni G, Munz G (2017a) Effect of cellulose as co-substrate on old landfill leachate treatment using white-rot fungi. Bioresour Technol 241:1067-1076. doi: 10.1016/j.biortech.2017.06.046

Bardi A, Yuan Q, Tigini V, Spina F, Varese GC, Spennati F, Becarelli S, Di Gregorio, S, Petroni G, Munz G (2017b) Recalcitrant compounds removal in raw leachate and synthetic effluents using the white-rot fungus Bjerkandera adusta. Water 9:824. doi: 10.3390/w9110824

Batra A, Saxena RK (2005) Potential tannase producers from the genera Aspergillus and Penicillium. Process Biochem 40:1553-1557. doi: 10.1016/j.procbio.2004.03.003

Battestin V, Alves-Macedo G (2007) Tannase production by Paecilomyces variotii. Bioresour Technol 98:18321837. doi: 10.1016/j.biortech.2006.06.031

Beena PS, Basheer SM, Bhat SG, Bahkali AH, Chandrasekaran M. (2011) Propyl gallate synthesis using acidophilic tannase and simultaneous production of tannase and gallic acid by marine Aspergillus awamori BTMFW032. Appl Biochem Biotechnol 164:612-628. doi: 10.1007/s12010-011-9162-x

Belmares R, Contreras-Esquivel JC, Rodriguez-Herrera R, Ramirez Coronel A, Aguilar CN (2004) Microbial production of tannase: an enzyme with potential use of food industry. LWT-Food Sci Technol 37:857-864. doi: 10.1016/j.lwt.2004.04.002

Bhat TK, Singh B, Sharma OP (1998) Microbial degradation of tannins - A current perspective. Biodegradation 9:343-357. doi:10.1023/A:1008397506963

Bhoite RN, Murthy PS (2015) Biodegradation of coffee pulp tannin by Penicillium verrucosum for production of tannase, statistical optimization and its application. Food Bioprod Process 94:727-735. doi: 10.1016/j.fbp.2014.10.007

Böer E, Bode R, Mock H-P, Piontek M, Kunze G (2009) Atan1p — an extracellular tannase from the dimorphic yeast Arxula adeninivorans: molecular cloning of the ATAN1 gene and characterization of the recombinant enzyme. Yeast 26:323--337. doi: 10.1002/yea.1669

Bradoo S, Gupta R, Saxena R (1996) Screening of extracellular tannase producing fungi: development of rapid simple plate assay. J Gen Appl Microbiol 42:325-329.

Bressan Gonçalves H, Jorge JA, Costa Pessela B, Fernandez Lorente G, Guisan JM, Souza Guimaraes LH (2013) Characterization of a tannase from Emericela nidulans immobilized on ionic and covalent supports for propyl gallate synthesis. Biotechnol Lett 35:591-598. doi: 10.1007/s10529-012-1111-4

Cabral LD, Pinto VF, Patriarca A (2013) Application of plant derived compounds to control fungal spoilage and mycotoxin production in foods. Int J Food Microbiol 166:1-14. doi: 10.1016/j.ijfoodmicro.2013.05.026 
Chambergo FS, Valencia EY (2016) Fungal biodiversity to biotechnology. Appl Microbiol Biotechnol 100:2567-2577. doi: 10.1007/s00253-016-7305-2

Chanda A, Gummadidala PM, Gomaa OM, (2016) Mycoremediation with mycotoxin producers: a critical perspective Appl. Microbiol. Biotechnol. 1:17-29. doi: 10.1007/s00253-015-7032-0

Chaudhary P, Chhokar V, Kumar A, Beniwal V (2017) Bioremediation of tannery wastewater. In: Kumar R., Sharma A., Ahluwalia S. (eds) Advances in Environmental Biotechnology. Springer, Singapore, pp. 125-144.

Chávez-González M, Rodríguez-Durán LV, Balagurusamy N, Prado-Barragán A, Rodríguez R, Contreras JC, Aguilar CN (2012) Biotechnological advances and challenges of tannase: an overview. Food Bioprocess Technol 5:445-459. doi: 10.1007/s11947-011-0608-5.

Crestini C, Lange H (2005) A novel and efficient immobilised tannase coated by the layer-by-layer technique in the hydrolysis of gallotannins and ellagitannins. Microchem J 123:139-147. doi: 0.1016/j.microc.2015.05.025

Cruz-Hernández M, Contreras-Esquivel JC, Lara F, Rodríguez R, Aguilar CN (2005) Isolation and evaluation of tannin-degrading fungal strains from the Mexican desert. Z Naturforsch C 60:844-848.

Doi S, Shinmyo A, Enatsu T, Terui G (1973) Growth associated production of tannase by a strain of Aspergillus oryzae. J Ferment Technol 61:768-774

El-Tanash AB, Sherief AA, Nour A (2011) Catalytic properties of immobilized tannase produced from Aspergillus aculeatus compared with free enzymes. Braz J Chem Eng 28(3):381-391. doi: 0.1590/S010466322011000300004

Elsherbiny EA, Amin BH, Baka ZA (2016) Efficiency of pomegranate (Punica granatum L.) peels extract as a high potential natural tool towards Fusarium dry rot on potato tubers. Postharvest Biol Technol 111:256-263. doi: 0.1016/j.postharvbio.2015.09.019

Endo EH, Garcia Cortez DA, Ueda-Nakamura T, Nakamura CV, Dias Filho BP (2010) Potent antifungal activity of extracts and pure compound isolated from pomegranate peels and synergism with fluconazole against Candida albicans Res Microbiol 161:534-540. doi: 10.1016/j.resmic.2010.05.002

European Pharmacopoeia (2005) Fifth edition, Vol 2, p. 2534, Council of Europe, Strasbourg

Evans TN, Seviour RJ (2012) Estimating biodiversity of fungi in activated sludge communities using cultureindependent methods. Microb Ecol 63:773-786. doi: 10.1007/s00248-011-9984-7

Farias GM, Gorbea C, Elkins JR, Griffin GJ (1994) Purification characterization and substrate relationships of the tannase from Cryphonectria parasitica. Physiol Mol Plant Pathol 44:51-63. doi: 10.1016/S08855765(05)80094-3 
Fathi S, Hajizadeh Y, Nikaeen M, Gorbani M (2017) Assessment of microbial aerosol emissions in an urban wastewater treatment plant operated with activated sludge process. Aerobiologia 33:507-515. doi: $10.1007 / \mathrm{s} 10453-017-9486-2$

Filgueira D, Moldes D, Fuentealba C, García DE (2017) Condensed tannins from pine bark: a novel wood surface modifier assisted by laccase. Ind Crops Prod 103:185-194. doi: 10.1016/j.indcrop.2017.03.040

Food and Agriculture Organization of the United Nations (2009) Compendium of food additive specifications, Joint FAO/WHO Expert Committee on Food Additives, 71st meeting 2009, p. 99. http://www.fao.org/3/ai0971e.pdf

Ganga PS, Nandy SC, Santappa M (1977) Effect of environmental factors on the production of fungal tannase. Leather Sci 24:8-16

Gao D, Zeng Y, Wen X, Qian Y (2008) Competition strategies for the incubation of white rot fungi under nonsterile conditions. Process Biochem 43:937-944. doi: 10.1016/j.procbio.2008.04.026

Giovando S, Pizzi A, Pasch H, Pretorius N (2013) Structure and oligomers distribution of commercial Tara (Caesalpinia spinosa) hydrolysable tannin. ProLigno, 9:22-31

Gnanamani A, Sekaran G, Babu M (2001) Removal of cross-linked and open chain polymeric tannin substrates using heme peroxidases of Phanerochaete chrysosporium. Bioprocess Biosyst Eng 24:211-217. Doi: $10.1007 / \mathrm{S} 004490100256$

González-García S, Feijoo G, Heathcote C, Kandelbauer A, Moreira MT (2011) Environmental assessment of green hardboard production coupled with a laccase activated system. J Clean Prod 19:445-453. doi: 10.1016/j.jclepro.2010.10.016

Govindarajan RK, Revathi S, Rameshkumar N, Krishnan M, Kayalvizhi M (2016) Microbial tannase: Current perspectives and biotechnological advances. Biocatalysis And Agricultural Biotechnology 6:168-175. doi: 10.1016/j.bcab.2016.03.011

Gupta PD, Birdi TJ (2017) Development of botanicals to combat antibiotic resistance. J Ayurveda Integr Med 8:266-275. doi: 10.1016/j.jaim.2017.05.004

Hadi TA, Banerjee R, Bhattacharya BC (1994) Optimization of tannase biosynthesis by a newly isolated Rhizopus oryzae. Bioprocess Eng 11:239-242. doi: 10.1007/s004490050075

Haslam E (1981) Vegetable tannins. In: Stumpf PK, Conn EE (eds) The Biochemistry of plants, Academic Press, London, pp 527-557

Haslam E (1996) Natural polyphenols (vegetable tannins) as drugs: possible modes of action. J Nat Prod 59:205-215. doi: 10.1021/np960040+ 
Haslam E, Stangroom JE (1966) The esterase and depside activities of the tannase. Biochem J 99:28-31

Haslan E (1996) Natural polyphenols (vegetable tannins) as drugs. Possible model of action. J Nat Prod 59:205215. doi: $10.1021 / \mathrm{np} 960040+$

He Q, Yao K, Sun D, Shi B (2007) Biodegradability of tannin-containing wastewater from leather industry. Biodegradation 18:465-472. doi: 10.1007/s10532-006-9079-1

Herrera Bravo de Laguna I, Toledo Marante FJ, Mioso R (2015) Enzymes and bioproducts produced by the ascomycete fungus Paecilomyces variotii. J Appl Microbiol 119:1455-1466. doi: 10.1111/jam.12934

Herrero M, Stuckey DC (2015) Bioaugmentation and its application in wastewater treatment: a review. Chemosphere 140:119-28. doi: 10.1016/j.chemosphere.2014.10.033

Hintermeyer BH, Tavani EL (2013) Adsorption, biosorption and bioaccumulation used to remove Chromium(III) from tanning wastewaters: a critical review. Soc Leather Technol Chem 97:231-237.

Hu Q, Luo C, Zhang Q, Luo Z (2013) Isolation and characterization of a Laccase gene potentially involved in proanthocyanidin polymerization in oriental persimmon (Diospyros kaki Thunb.) fruit. Mol Biol Rep 40:28092820. doi: 10.1007/s11033-012-2296-2

Huang W, Li Z, Niu H, Li L, Lin W, Yang J et al. (2007) Utilization of acorn fringe for ellagic acid production by Aspergillus oryzae and Endomyces fibuliger. Bioresour Technol 99:3552-3558. doi: 10.1016/j.biortech.2007.07.047

Iibuchi S, minoda Y, Yamada K (1967) Studies on tannin acyl hydrolase of microorganisms. Part II. A new method determining the enzyme activity using the change of ultra violet absorption. Agric Biol Chem 31:513518

Ijoma GN, Tekere M (2017) Potential microbial applications of co-cultures involving ligninolytic fungi in the bioremediation of recalcitrant xenobiotic compounds. Int J Environ Sci Technol 14:1787-1806. doi: $10.1007 / \mathrm{s} 13762-017-1269-3$

Institute of Medicine (2003) Food Chemicals Codex: Fifth Edition. Washington, DC: The National Academies Press. https://doi.org/10.17226/10731.

Iqbal HMN, Kyazze G, Tron T, Keshavarz T, (2018) Laccase from Aspergillus niger: A novel tool to graft multifunctional materials of interests and their characterization. Saudi J Biol Sci 25:545-550. doi: 10.1016/j.sjbs.2016.01.027

Itoh N, Takagi S, Miki A, Kurokaw J (2016) Characterization and cloning of laccase gene from Hericium coralloides NBRC 7716 suitable for production of epitheaflagallin 3-O-gallate. Enzyme Microb Technol 82:125-132. doi: 10.1016/j.enzmictec.2015.09.004 
Jana A, Maity C, Halder SK, Mondal KC, Pati BR, Das Mohapatra PK (2012) Tannase production by Penicillium purpurogenum PAF6 in solid state fermentation of tannin-rich plant residues following OVAT and RSM. Appl Biochem Biotechnol 167:1254-1269. doi: 10.1007/s12010-012-9547-5

Janusz G, Pawlik A, Sulej J, Swiderska-Burek U, Jarosz-Wilkołazka A, Paszczynski A (2017) Lignin degradation: microorganisms, enzymes involved, genomes analysis and evolution. FEMS Microbiol Rev 41:941-962. doi: 0.1093/femsre/fux049

Jiménez N, Curiel JA, Reverón I, de las Rivas B, Muñoz R (2013) Uncovering the Lactobacillus plantarum WCFS1 gallate decarboxylase involved in tannin degradation. Appl Environ Microbiol 79(14):4253-4263. doi: 10.1128/AEM.00840-13

Karpe AV, Beale DJ, Godhani NB, Morrison PD, Harding IH, Palombo EA (2015) Untargeted metabolic profiling of winery-derived biomass waste degradation by Penicillium chrysogenum. J Agric Food Chem 63:10696-10704. doi: 10.1021/acs.jafc.5b04834

Kasieczka-Burnecka M, Kuc K, Kalinowska H, Knap M, Turkiewicz M (2007) Purification and characterization of two cold-adapted extracellular tannin acyl hydrolases from an Antarctic strain Verticillium sp. P9. Appl Microbiol Biotechnol 77:77-89. doi: 10.1007/s00253-007-1124-4

Kharchoufi S, Licciardello F, Siracusa L, Muratore G, Hamdi M, Restuccia C (2018) Antimicrobial and antioxidant features of "Gabsi" pomegranate peel extracts. J Indcrop 111:345-352. doi: 10.1016/j.indcrop.2017.10.037

Knudson L (1913) Tannic acid fermentation. J Biol Chem 14:159-184

Kumar S, Beniwal V, Kumar N, Kumar A, Chhokar V, Khaket TP (2015) Biochemical characterization of immobilized tannase from Aspergillus awamori. Biocatal Agric Biotechnol 4:398-403. doi: 10.1016/j.bcab.2015.07.004

Lekha P, Lonsane B (1994) Comparative titres, location and properties of tannin acyl hydrolase produced by Aspergillus niger PKL 104 in solid-state, liquid surface and submerged fermentations. Process Biochem 29:497503

Lekha PK, Lonsane, BK (1997) Production and application of tannin acyl hydrolase: state of the art. Adv Appl Microbiol 44:215-260. doi: 10.1016/S0065-2164(08)70463-5

Lewis JA, Starkey RL (1969) Decomposition of plant tannins by some soil microorganisms. Soil Sci 107:235241

Leyva-Diaz J, Martin-Pascual J, Poyatos JM (2017) Moving bed biofilm reactor to treat wastewater. Int J Environ Sci Technol 14:881-910. doi: 10.1007/s13762-016-1169-y 
Li MS, Yao K, He Q, Jia DY (2006) Biodegradation of gallotannins and ellagitannins. J Basic Microbiol 46:6884. doi: $10.1002 /$ jobm. 200510600

Liu J, Li J, Tao Y, Sellamuthu B, Walsh R (2017) Analysis of bacterial, fungal and archaeal populations from a municipal wastewater treatment plant developing an innovative aerobic granular sludge process. World $\mathrm{J}$ Microbiol Biotechnol 33:14. doi: 10.1007/s11274-016-2179-0

Lofrano G, Meric S, Zengin GE, Orhon D (2013) Chemical and biological treatment technologies for leather tannery chemicals and wastewaters: a review. Sci Total Environ 461:265-281. doi: 10.1016/j.scitotenv.2013.05.004

Ma W, Zhao F, Ye Q, Hu Z, Yan D, Hou J, Yang Y (2015) Production and partial purification of tannase from Aspergillus ficuum Gim 3.6. Prep Biochem Biotechnol 45:754-768. doi: 10.1080/10826068.2014.952384

Mahapatra K, Nanda RK, Bag SS, Banerjee R, Pandey A, Szakacs G (2005) Purification, characterization and some studies on secondary structure of tannase from Aspergillus awamori Nakazawa. Process Biochem 40:3251-3254. doi: 10.1016/j.procbio.2005.03.034

Mahendran B, Raman N, Kim D (2005) Purification and characterization of tannase from Paecilomyces variotii: hydrolysis of tannic acid using immobilized tannase. Appl Microbiol Biotechnol 70:445-451. doi: $10.1007 / \mathrm{s} 00253-005-0082-\mathrm{y}$

Martinez AT (2002) Molecular biology and structure-function of lignin-degrading heme peroxidases. Enzyme Microb Technol 30:425-444. doi: 10.1016/S0141-0229(01)00521-X

Mata-Gómez M, Mussatto SI, Rodríguez R, Teixeira JA, Martinez JL, Hernandez A, Aguilar CN (2009) Gallic acid production with mouldy polyurethane particles obtained from solid state culture of Aspergillus niger GH1. Appl Biochem Biotechnol 176:1131-1140. doi: 10.1007/s12010-015-1634-y

Meier AK, Worch S, Böer E, Hartmann A, Mascher M, Marzec M, Scholz U, Riechen J, Baronian K, Schauer F, Bode R and Kunze G (2017) Agdc1p - a Gallic acid decarboxylase involved in the degradation of tannic acid in the yeast Blastobotrys (Arxula) adeninivorans. Front Microbiol 8:1777. doi: 10.3389/fmicb.2017.01777

Mishra V, Jana AK (2017) Fungal pretreatment of sweet sorghum bagasse with combined $\mathrm{CuSO}_{4}$-gallic acid supplement for improvement in lignin degradation, selectivity, and enzymatic saccharification. Appl Biochem Biotechnol 183:200-217. doi: 10.1007/s12010-017-2439-y

Mishra V, Jana AK, Jana MM, Gupta A (2017) Synergistic effect of syringic acid and gallic acid supplements in fungal pretreatment of sweet sorghum bagasse for improved lignin degradation and enzymatic saccharification. Process Biochem 55:116-125. doi: 10.1016/j.procbio.2017.02.011 
Moreira F, Boaventura RAR, Brillas E, Vilar VJP (2015) Remediation of a winery wastewater combining aerobic biological oxidation and electrochemical advanced oxidation processes. Water Res 75:95-108. 10.1016/j.watres.2015.02.029

Mueller-Harvey I, McAllan AB (1992) Tannins. Their biochemistry and nutritional properties. In: Morrison IM (ed) Advances in plant cell biochemistry and biotechnology. JAI Press Ltd., London, pp 151-217

Munz G, De Angelis D, Goria R, Moric G, Casarci M, Lubello C (2009) The role of tannins in conventional and membrane treatment of tannery wastewater. J Hazard Mater 164:733-739. doi: 10.1016/j.jhazmat.2008.08.070

Murugan K, Saravanababu S, Arunachalam M (2007) Screening of tannin acyl hydrolase (EC.3.1.1.20) producing tannery effluent fungal isolates using simple agar plate and SmF process. Bioresour Technol 98:946949. doi: 10.1016/j.biortech.2006.04.031

Mutabaruka R, Hairiah K, Cadisch G (2007) Microbial degradation of hydrolysable and condensed tannin polyphenol-protein complexes in soils from different land-use histories. Soil Biol Biochem 39:1479-1492. doi: 10.1016/j.soilbio.2006.12.036

Natarajan R, Manivasagan R (2018) Treatment of tannery effluent by passive uptake parametric studies and kinetic modeling. Environ Sci Pollut Res 25:5071-5075. doi: 10.1007/s11356-017-9456-9

Niemetz R, Gross GG (2005) Enzymology of gallotannin and ellagitannin biosynthesis. Phytochemistry 66:2001-2011. doi: 10.1016/j.phytochem.2005.01.009

Ong C-B. Annuar MSM (2018) Immobilization of cross-linked tannase enzyme on multiwalled carbon nanotubes and its catalytic behavior. Prep Biochem Biotechnol 48(2):181-187. doi: $10.1080 / 10826068.2018 .1425707$

Ordonez RM, Colombo I, Alberto MR, Isla MI (2011) Production of tannase from wooddegrading fungus using as substrate plant residues: purification and characterization. World J Microbiol Biotechnol 27:2325-2333. doi: 10.1007/s11274-011-0699-1

Pane C, Fratianni F, Parisi M, Nazzaro F, Zaccardelli M (2016) Control of Alternaria post-harvest infections on cherry tomato fruits by wild pepper phenolic-rich extracts. Crop Prot 84:81-87. doi: 10.1016/j.cropro.2016.02.015

Panno L, Bruno M, Voyron S, Anastasi A, Gnavi G, Miserere L, Varese GC (2013) Diversity, ecological role and potential biotechnological applications of marine fungi associated to the seagrass Posidonia oceanica. New Biotech 30:685-694. doi: 10.1016/j.nbt.2013.01.010

Pasch H, Pizzi A (2002) Considerations on the macromolecular structure of chestnut ellagitannins by matrixassisted laser desorption/ionization-time-of-flight mass spectrometry. J Appl Polymer Sci, 85:429-437. doi: 10.1002/app.10618 
Pasch H, Pizzi A, Rode K (2001) MALDI-TOF mass spectrometry of polyflavonoid tannins. Polymer 42:75317539. doi: 10.1016/S0032-3861(01)00216-6

Perovano N, da Silva KF, Lopez AMQ (2011) Fungic decomposition of tannic acid and other compounds from agri-industrial effluent. Acta Sci-Technol 33:145-153. doi: 10.4025/actascitechnol.v33i2.10117

Piscitelli A, Giardina P, Lettera V, Pezzella C, Sannia G, Farmaco V (2011) Induction and transcriptional regulation of laccases in fungi. Curr Genomics 12:104-112. doi: 10.2174/138920211795564331

Pizzi A, Pasch H, Rode K, Giovando S (2009) Polymer structure of commercial hydrolyzable tannins by matrixassisted laser desorption/ionization-time-of-flight mass spectrometry. J. Appl Polymer Sci, 113:3847-3859. doi: 10.1002/app.30377

Plodpai P, Chuenchitt S, Petcharat V, Chakthong S, Voravuthikunchai SP (2013) Anti-Rhizoctonia solani activity by Desmos chinensis extracts and its mechanism of action. Crop Prot 43:65-71. doi: 10.1016/j.cropro.2012.09.004

Prashanth D, Asha MK, Amit A (2001) Antibacterial activity of Punica granatum. Fitoterapia 72:171-173. doi: $10.1016 / \mathrm{S} 0367-326 \mathrm{X}(00) 00270-7$

Prigione V, Trocini B, Spina F, Poli A, Romanisio D, Giovando S, Varese GC (2018) Fungi from industrial tannins: potential application in biotransformation and bioremediation of tannery wastewaters. Appl Microbiol Biotechnol 102:4203-4216. doi: 10.1007/s00253-018-8876-x

Purohit JS, Dutta JR, Nanda RK, Banerjee R (2006) Strain improvement for tannase production from co-culture of Aspergillus foetidus and Rhizopus oryzae. Bioresour Technol 97:795-801. doi: 10.1016/j.biortech.2005.04.031

Radebe N, Rode K, Pizzi A, Giovando S, Pasch H (2013) MALDI-TOF-CID for the microstructure elucidation of polymeric hydrolysable tannins. J Appl Polym.Sci 128:97-107. doi: 10.1002/app.38156

Raghuwanshi S, Misra S, Kumar Saxena R (2014) Treatment of wheat straw using tannase and white-rot fungus to improve feed utilization by ruminants. J Anim Sci Biotechnol 5:13. doi: 0.1186/2049-1891-5-13

Rajakumar GS, Nandy SC (1983) Isolation, purification, and some properties of Penicillium chrysogenum tannase. Appl Environ Microbiol 46:525-527

Ramos EL, Mata-Gómez MA, Rodríguez-Durán LV, Belmares RE, Rodríguez-Herrera R, Aguilar CN (2011) Catalytic and thermodynamic properties of a tannase produced by Aspergillus niger GH1 grown on polyurethane foam. Appl Biochem Biotechnol 165:1141 -1151. doi: 10.1007/s12010-011-9331-y

Rana N, Bhat T (2005) Effect of fermentation system on the production and properties of tannase of Aspergillus niger van Tieghem MTCC 2425. J Gen Appl Microbiol 51:203-212. doi: 10.2323/jgam.51.203 
Rao MA, Scelza R, Acevedo F, Diez MC, Gianfreda L (2014) Enzymes as useful tools for environmental purposes. Chemosphere 107:145-162. doi: 10.1016/j.chemosphere.2013.12.059

Ratto M, Ritschkoff A-C, Viikari L (2004) Enzymatically polymerized phenolic compounds as wood preservatives. Holzforschung 58: 440-445. doi: 10.1515/HF.2004.067

Ravichandran A, Sridhar M (2017) Insights into the mechanism of lignocellulose degradation by versatile peroxidases. Curr Sci 110(1):35-42. doi: 10.18520/cs/v113/i01/35-42

Rene ER, Veiga MC, Kennes C (2010) Biodegradation of gas-phase styrene using the fungus Sporothrix variecibatus: impact of pollutant load and transient operation. Chemosphere 79:221-227. doi: 10.1016/j.chemosphere.2010.01.036

Reverón I, Jiménez N, Curiel JA, Peñas E, López de Felipe F, de las Rivas B, Muñoz R (2017) Differential gene expression by Lactobacillus plantarum WCFS1 in response to phenolic compounds reveals new genes involved in tannin degradation. Appl Environ Microbiol 83:03387-16. doi: 10.1128/AEM.03387-16

Sabu A, Pandey A, Jaafar Daud M, Szakacs G (2005) Tamarind seed powder and palm kernel cake: two novel agro residues for the production of tannase under solid state fermentation by Aspergillus niger ATCC 16620. Bioresour Techno 96:1223-1228. doi: 10.1016/j.biortech.2004.11.002

Sáez-Jiménez V, Fernández-Fueyo E, Medrano FJ, Romero A, Martínez AT, Ruiz-Dueñas FJ (2015) Improving the $\mathrm{pH}$-stability of versatile peroxidase by comparative structural analysis with a naturally-stable manganese peroxidase. PLoS ONE 10(10):e0140984. doi: 10.1371/journal.pone.0140984

Sahay R, Yadav RSS, Yadav KDS (2009) Purification and characterization of laccase secreted by L. lividus. Appl Biochem Biotechnol 157:311-332. doi: 10.1007/s12010-008-8265-5

Scalbert A (1991) Antimicrobial properties of tannins. Phytochemistry 30:3875-3883.

Schons PF, Rezende Lopes FC, Battestin V, Macedo GA (2011) Immobilization of Paecilomyces variotii tannase and properties of the immobilized enzyme. J Microencapsul 28(3):211-219. doi: $10.3109 / 02652048.2011 .552988$

Serrani Valera L, Jorge JA, Souza Guimarães LH (2015) Characterization of a multi-tolerant tannin acyl hydrolase II from Aspergillus carbonarius produced under solid-state fermentation. Electron J Biotechnol 18:464-470. doi: 10.1016/j.ejbt.2015.09.008

Sharma S, Bhat TK, Gupta MN (2002) Bioaffinity immobilization of tannase from Aspergillus niger on concanavalin A-Sepharose CL-4B. Biotechnol Appl Biochem 35:165-169. doi: 10.1042/BA20010084 
Sietmann R, Uebe R, Boer E, Bode R, Kunze G, Schauer F (2010) Novel metabolic routes during the oxidation of hydroxylated aromatic acids by the yeast Arxula adeninivorans. J Appl Microbiol 108:789-799. doi: 10.1111/j.1365-2672.2009.04474.x

Silva de Lima J, Cabrera MP, de Souza Motta CM, Converti A, Carvalho Jr LB (2018) Hydrolysis of tannins by tannase immobilized onto magnetic diatomaceous earth nanoparticles coated with polyaniline. Food Res Int 107:470-476. doi: 10.1016/j.foodres.2018.02.066

Silva de Lima J, Cruz R, Cordoville Fonseca J, Valente de Medeiros E, de Holanda Cavalcanti Maciel M, Aparecida Moreira K, de Souza Motta C (2014) Production, characterization of tannase from Penicillium montanense URM 6286 under SSF using agroindustrial wastes, and application in the clarification of grape juice (Vitis vinifera L.). Scientific World J 2014:1-9. doi:10.1155/2014/182025

Song Z, Burns RG (2005) Depolymerisation and biodegradation of a synthetic tanning agent by activated sludges, the bacteria Arthrobacter globiformis and Comamonas testosteroni, and the fungus Cunninghamella polymorpha. Biodegradation 16:305-318. doi: 10.1007/s10532-004-1723-z

Spennati F (2018) Use of fungi and bacteria for the removal of recalcitrant compounds from tannery wastewater. PhD Thesis. Department of Civil and Environmental Engineering University of Florence and Department of Chemical, Biological and Environmental Engineering Autonomous University of Barcelona

Spennati F, Mora M, Guisasola A, Bardi A, Tigini V, Gabriel D, Munz G (2017) Quebracho tannin treatment with Aspergillus tubingensis MUT 990 immobilized in polyurethane foam cubes in a novel submerged cage reactor. In Book of abstracts of 10th International Conference on Biofilm Reactors. Dublin, Ireland, 9-12 May 2017.

Spennati F, Tigini V, Spina F, Varese GC, Bardi A, Siracusa G, Becarelli S, Di Gregorio, S, Petroni, G, Mori G, Munz, G (2016) Enhancing the tannins biodegradation with Aspergillus tubingensis and Chaetomium sp.: cosubstrates batch tests. In: SIDISA 2016, X international symposium on sanitary and environmental engineering, pp. 1-9. Rome, Italy, 19-23 June 2016.

Spina F, Romagnolo A, Anastasi A, Tigini V, Prigione V, Varese GC (2012) Selection of strains and carriers to combine fungi and activated sludge in wastewater bioremediation. Environ Eng Manag J 11:1789-1796.

Svobodová K, Novotný C (2018) Bioreactors based on immobilized fungi: bioremediation under non-sterile conditions. Appl Microbiol Biotechnol 102:39-46. doi: 10.1007/s00253-017-8575-z

Tagger S, Perissol C, Gil G, Vogt G, Le Pet J (1998) Phenoloxidases of the white-rot fungus Marasmius quercophilus isolated from an evergreen oak litter (Quercus ilex L.). Enzyme Microb Technol 23:372-379. doi: 10.1016/S0141-0229(98)00062-3 
Tehranifar A, Selahvarzi Y, Kharrazi M, Bakhsh VJ (2011) High potential of agro-industrial by-products of pomegranate (Punica granatum L.) as the powerful antifungal and antioxidant substances. Ind Crop Prod 34:1523-1527. doi: 10.1016/j.indcrop.2011.05.007

Tigini V, Bevione F, Prigione V, Poli A, Ranieri L, Spennati F, Munz G, Varese GC (2018) Tannery mixed liquors froman ecotoxicological and mycological point of view: Risks vs potential biodegradation application, Sci Tot Environ 627:835-843. doi: 10.1016/j.scitotenv.2018.01.240

Tigini V, Varese GC (2018) Biosorption with autochthonous and allochthonous fungal biomasses for bioremediation and detoxification of landfill leachate. Environ Earth Sci 77:342. doi: 10.1007/s12665-018$7519-\mathrm{y}$

Tomás-Cortázar J, Plaza-Vinuesa L, de las Rivas B, Lavín JJ, Barriales D, Abecia L, Mancheño JM, Aransay AM, Muñoz R, Anguita J, Rodríguez H (2018) Identification of a highly active tannase enzyme from the oral pathogen Fusobacterium nucleatum subsp. polymorphum. Microbial Cell Factories 17:33. doi: 10.1186/s12934018-0880-4

Van de Lagemaat J, Pyle DL (2005) Modelling the uptake and growth kinetics of Penicillium glabrum in a tannic acid-containing solid-state fermentation for tannase production. Process Biochem 40:1773-1782. doi: 10.1016/j.procbio.2004.06.044

Vasconcelos LCS, Sampaio MCC, Sampaio FC, Higino JS (2003) Use of Punica granatum as an antifungal agent against candidosis associated with denture stomatitis. Mycoses 46:192-196.

Vattem DA, Shetty K (2002) Solid-state production of phenolic antioxidants from cranberry pomace by Rhizopus oligosporus. Food Biotechnol 16:189-210. doi: 10.1081/FBT-120016667

Vattem DA, Shetty K (2003) Ellagic acid production and phenolic antioxidants activity in cranberry pomace (Vaccinium macrocarpon) mediated by Lentinus edodes using a solid-state system. Process Biochem 39:367379. doi: 0.1016/S0032-9592(03)00089-X

Venter PB, Sisa M, Van der Merwe MJ, Bonnet SL, Van der Westhuizen JH (2012) Analysis of commercial proanthocyanidins. Part 1: The chemical composition of quebracho (Schinopsis lorentzii and Schinopsis balansae) heartwood extract. Phytochemistry 73:95-105. doi: 10.1016/j.phytochem.2011.10.006

Vepsalainen M, Kivisaari H, Pulliainen M, Oikari A, Sillanpaa M (2011) Removal of toxic pollutants from pulp mill effluents by electrocoagulation. Sep Pur Technol 81:141-150. doi: 10.1016/j.seppur.2011.07.017

Voravuthikunchai SP, Sririrak T, Limsuwan S, Supawita T, Iida T, Honda T (2005) Inhibitory effects of active compounds from Punica granatum pericarp on verocytotoxin production by enterohemorrhagic Escherichia coli O157:H7. J Health Sci 51:590-596. doi: 10.1248/jhs.51.590 
Widsten P, Hummer A, Heathcote C, Kandelbauer A (2009) A preliminary study of green production of fiberboard bonded with tannin and laccase in a wet process. Holzforschung 63:545-550. doi: 10.1515/HF.2009.090

Wu, CZ, Zhang F, Li LJ, Jiang,ZD, Ni H, Xiao, AX (2018) Novel optimization strategy for tannase production through a modified solid-state fermentation system. Biotechnology For Biofuels 11:92. doi: 10.1186/s13068018-1093-0

Yague S, Terron MC, Gonzalez T, Zapico E, Bocchini P, Galletti GC, Gonzalez AE (2000) Biotreatment of tannin-rich beer-factory wastewater with white-rot basidiomycete Coriolopsis gallica monitored by pyrolysis/gas chromatography/mass spectrometry. Rapid Comm Mass Spectrom 14:905-910. doi: 10.1002/(SICI)1097-0231(20000530)14:10<905::AID-RCM963>3.0.CO;2-7

Yamada H, Adachi C, Watanabe M, Sato N (1968) Studies of fungal tannase. Part I. formation, purification and catalytic properties of tannase of Aspergillus flavus. Agric Biol Chem 32:1070-1078

Yamaguchi H, Maeda Y, Sakata I (1998) Applications of phenol dehydrogenative polymerization by laccase to bonding among woody-fibers. Mokuzai Gakkaishi 38:931-937.

Yao J, Guo GS, Ren GH, Liu YH (2014) Production, characterization and applications of tannase. J Mol Catal B Enzym 101:137- 147. doi: 10.1016/j.molcatb.2013.11.018

Yu X, Li Y, Wang C, Wu D (2004) Immobilization of Aspergillus niger tannase by microencapsulation and its kinetic characteristics. Biotechnol Appl Biochem 40:151-155. doi: 10.1042/BA20030180

Zakipour-Molkabadi E, Hamidi-Esfahani Z, Sahari MA, Azizi MH (2013) A New native source of tannase producer, Penicillium sp. EZ-ZH190: characterization of the enzyme. Iran J Biotechnol 11(4): 244-250. doi: $10.5812 / \mathrm{ijb} .11848$

Zeida M, Weiser M, Yoshida T, Sugio T, Nagasawa T (1998) Purification and characterization of gallic acid decarboxylase from Pantoea agglomerans T71. Appl Environ Microbiol 64(12):4743-4747.

Zerva A, Manos N, Vouyiouka S, Christakopoulos P, Topakas E (2016) Bioconversion of biomass-derived phenols catalyzed by Myceliophthora thermophila laccase. Molecules 21:550. doi: 10.3390/molecules21050550

Zhang S, Gao X, He L, Qiu Y, Zhu H, Cao Y (2015) Novel trends for use of microbial tannases. Prep. Biochem. Biotech. 45:221-232. doi: 10.1080/10826068.2014.907182

Zheng ZX, Shetty K (2000) Solid-state bioconversion of phenolics from cranberry pomace and role of Lentinus edodes beta-glucosidase. J Agric Food Chem 48:895-900. doi: 10.1021/jf990972u 
Table 1 Filamentous fungi capable of producing tannases and/or of using tannins as sole carbon source.

\begin{tabular}{|c|c|}
\hline Fungus & Reference \\
\hline Ascochyta boltshauseri & Lekha and Losane 1997 \\
\hline Ascochyta pisi & Lekha and Losane 1997 \\
\hline Ascochyta viciae & Lekha and Losane 1997 \\
\hline Aspergillus acidus & Prigione et al. 2018 \\
\hline Aspergillus aculeatus & Banerjee et al. 2001; El-Tanash et al. 2011 \\
\hline Aspergillus aureus & Bajpai and Patil 1997 \\
\hline Aspergillus awamori & $\begin{array}{l}\text { Bradoo et al. 1996; Mahapatra et al. 2005; Beena et al. 2011; Prigione } \\
\text { et al. } 2018\end{array}$ \\
\hline Aspergillus caespitosus & Batra and Saxena 2005 \\
\hline Aspergillu carbonarius & Serrani Valera et al. 2015 \\
\hline Aspergillus carneus & Ganga et al. 1977 \\
\hline Aspergillus costaricaensis & Prigione et al. 2018 \\
\hline Aspergillus ficuum & Ma et al. 2015 \\
\hline Aspergillus fischeri & Bajpai and Patil 1997 \\
\hline Aspergillus flavipes & Ganga et al. 1977 \\
\hline Aspergillus flavus & Yamada et al. 1968; Batra and Saxena 2005 \\
\hline Aspergillus foetidus & Banerjee et al. 2001 \\
\hline Aspergillus fumigatus & Batra and Saxena 2005 \\
\hline Aspergillus japonicus & Ganga et al. 1977; Bradoo et al. 1996 \\
\hline Aspergillus nidulans & Ganga et al. 1977 \\
\hline Aspergillus niger & $\begin{array}{l}\text { Knudson 1913; Haslam and Stangroom 1966; Lekha and Lonsane } \\
\text { 1994; Bradoo et al. 1996; Rana and Bhat 2005; Cruz-Hernandez et al. } \\
\text { 2005; Murugan et al. 2007; Prigione et al. } 2018\end{array}$ \\
\hline Aspergillus oryzae & $\begin{array}{l}\text { Iibuchi et al. 1967; Doi et al. 1973; Bajpai and Patil 1996; Bradoo et } \\
\text { al. 1996; Huang et al. 2007; Abdel-Naby et al. } 2016\end{array}$ \\
\hline Aspergillus parasiticus & Ganga et al. 1977; Bajpai and Patil 1996 \\
\hline Aspergillus tamarii & Lekha and Losane 1997 \\
\hline Aspergillus terreus & Ganga et al. 1977; Bajpai and Patil 1997 \\
\hline Aspergillus tubingensis & Prigione et al. 2018 \\
\hline Aspergillus ustus & Ganga et al. 1977 \\
\hline Aspergillus vadensis & Prigione et al. 2018 \\
\hline Aspergillus versicolor & Batra and Saxena 2005 \\
\hline Chaetomium globosum & Lekha and Losane 1997 \\
\hline Cryphonectria parasitica & Farias et al. 1994 \\
\hline Cunninghamella sp. & Bradoo et al. 1996 \\
\hline Emericella nidulans & Bressan Gonçalves et al. 2013 \\
\hline Fusarium oxysporum & Bradoo et al. 1996 \\
\hline Fusarium solani & Bajpai and Patil 1996; Bradoo et al. 1996 \\
\hline Helicostylum sp. & Bradoo et al. 1996 \\
\hline Lentinus edodes & Zheng and Shetty 2000; Vattem and Shetty 2003 \\
\hline Lenzites elegans & Ordonez et al. 2011 \\
\hline Mucor sp. & Belmares et al. 2004 \\
\hline Myrothecium verrucaria & Lekha and Losane 1997 \\
\hline Neurospora crassa & Bradoo et al. 1996 \\
\hline Paecilomyces variotii & $\begin{array}{l}\text { Mahendran et al. 2005; Battestin and Alves-Macedo 2007; Schons et } \\
\text { al. 2011; Herrera Bravo de Laguna et al. 2015; Prigione et al. } 2018\end{array}$ \\
\hline Penicillim crustosum & Batra and Saxena 2005 \\
\hline Penicillium charlesii & Bradoo et al. 1996 \\
\hline Penicillium chrysogenum & $\begin{array}{l}\text { Rajakumar and Nandy 1983; Bajpai and Patil 1996; Bradoo et al. } \\
\text { 1996; Karpe et al. } 2015\end{array}$ \\
\hline Penicillium citrinum & Bradoo et al. 1996 \\
\hline
\end{tabular}




\begin{tabular}{|l|l|}
\hline Penicillium corylophilum & Bradoo et al. 1996 \\
\hline Penicillium digitatum & Bradoo et al. 1996 \\
\hline Penicillium fellutanum & Ganga et al. 1977 \\
\hline Penicillium glabrum & Van de Lagemaat and Pyle 2005 \\
\hline Penicillium glaucum & Lekha and Losane 1997 \\
\hline Penicillium islandicum & Ganga et al. 1977 \\
\hline Penicillium minioluteum & Prigione et al. 2018 \\
\hline Penicillium montanense & Silva de Lima et al. 2014 \\
\hline Penicillium notatum & Ganga et al. 1977 \\
\hline Penicillium restrictum & Batra and Saxena 2005 \\
\hline Penicillium spinulosum & Prigione et al. 2018 \\
\hline Penicillium variabile & Batra and Saxena 2005 \\
\hline Penicillium verrucosum & Bhoite and Murthy 2015 \\
\hline Rhizopus oligosporus & Vattem and Shetty 2002 \\
\hline Rhizopus oryzae & Hadi et al. 1994; Purohit et al. 2006 \\
\hline Syncephalastrum racemosum & Bradoo et al. 1996 \\
\hline Talaromyces subinflatus & Prigione et al. 2018 \\
\hline Trichoderma hamatum & Bradoo et al. 1996 \\
\hline Trichoderma harzianum & Bradoo et al. 1996 \\
\hline Trichoderma viride & Bajpai and Patil 1996; Bradoo et al. 1996 \\
\hline Trichothecium roseum & Lekha and Losane 1997 \\
\hline Verticillium sp. & Kasieczka-Burnecka et al. 2007 \\
\hline
\end{tabular}




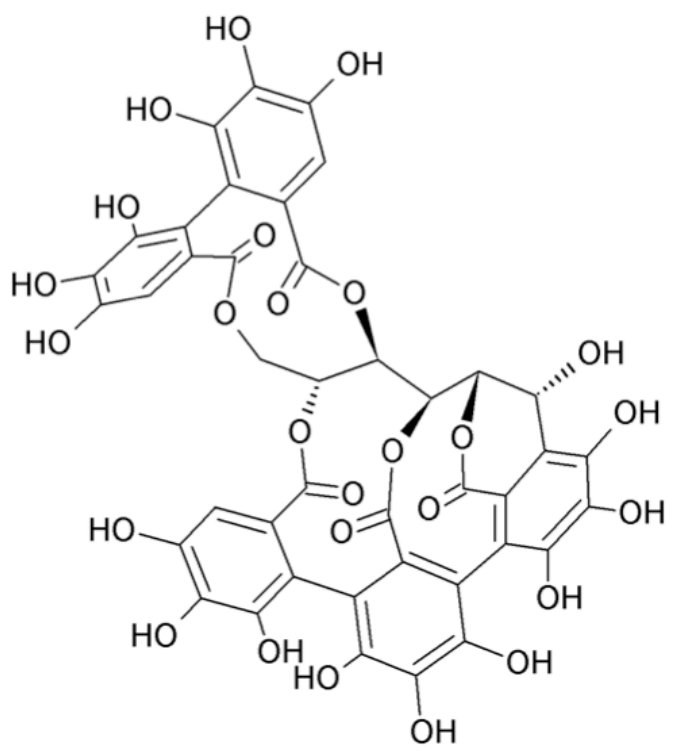

Fig. 1 Molecular structure of castalagin, the main component in the chestnut tannin 


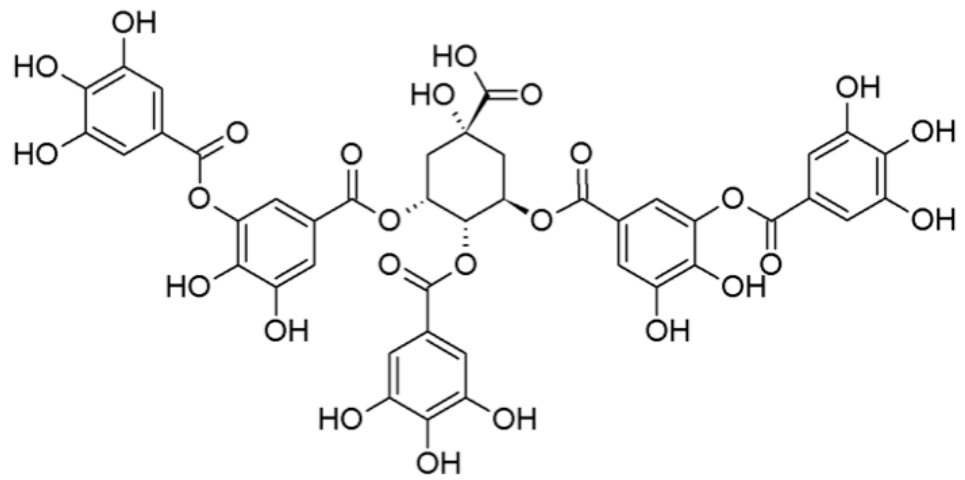

Fig. 2 Molecular structure of pentagalloyl quinic acid, the main component in the tara tannin 


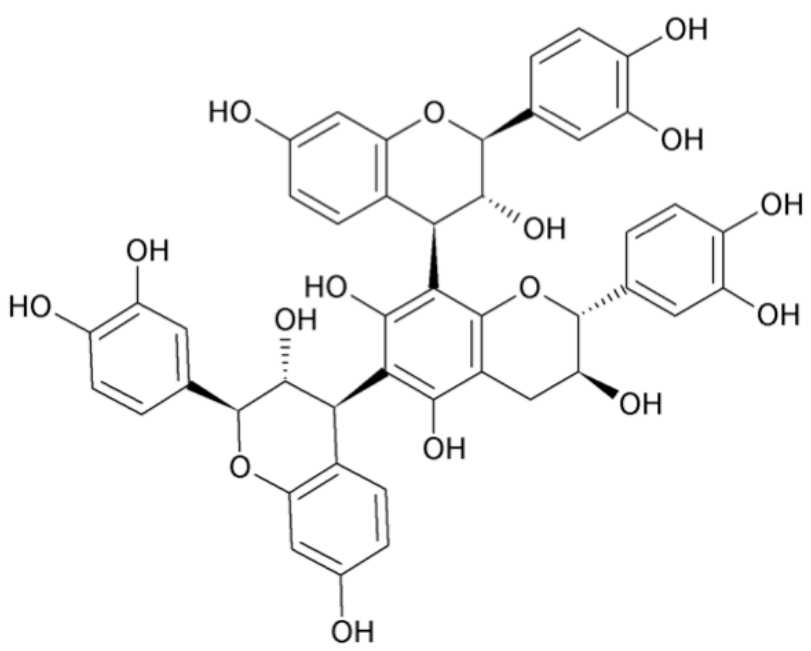

Fig. 3 Molecular structure of fisetinidin trimer, the main component in the quebracho tannin 